\title{
Students' Attitude Toward Extensive Reading at English Education Study Program in IAIN Bukittinggi
}

\author{
Veni Roza ${ }^{1}, Z^{2 a m r a t u l ~ K h a i r a n i}{ }^{2}$ \\ \{veniroz_501@yahoo.com¹,2315043zamratul@gmail.com²\}
}

Faculty of Tarbiyah and Teacher Training, Institut Agama Islam Negeri (IAIN) Bukittinggi, Indonesia ${ }^{1,2}$

\begin{abstract}
The research was due to several problems found in the field; the students were reluctant to read because students found some difficult words. Then, the students read one textin a week for the sake of writing weekly extensive reading report so that the researchers assumed that the students had bad reading habit. Then, the research aims to know students' attitude toward extensive reading in the aspects of affective, cognitive and behavior. This research belongs to quantitative research by survey. The population was the second semester English Education Study Program studentsof IAIN Bukittinggi. To choose sample, the researcher used total sampling. The finding reveals that students' attitude toward extensive reading in the aspect of affective is 3.56 which remarks good attitude. In addition, the students' attitude toward extensive reading in the aspect of cognitive is 3.82 which indicates the good attitude as well. The students' attitude toward extensive reading in the aspect of behavior is 3.36 that denotes good attitude. In conclusion, they perceive extensive reading is beneficial and joyful for them.
\end{abstract}

Keywords. attitude, extensive reading

\section{Introduction}

Reading is an active process which needs attention to get the meaning of the text. Similarly, Kathy G. Short (Short,1996:105)says that reading is an active process which reader constructs the meaning from a text because reader brings different experiences and knowledge so, each reader will have different interpretation about a text. In other words, reading does not only read letters and symbols but also a process to understand the meaning, accepts opinions, compares the theory and rejects the opinion that includes in the text. It means reading as thinking andreasoning. Then, there are two reading approaches that can apply in reading (Erfanpour, 2014:1). First reading approach is intensive reading. It is one approach where reading learns through the text which is under guidance of lecturer and task in order to make students focuses on the text. It focuses on reading comprehension with uses translation to make students understand with the text. It is taught by using grammar translation approach where teacher works with the students and uses first language to explain the text, sentences to sentences. Besides, it focuses on vocabulary and language features where teacher teaches the vocabulary and language features that includes in the text. The second reading approach is extensive reading. It is used in university as a subject called extensive reading. It is used to reach some purposes such as making reading a fun activity for students that able to increase student's critical thinking and ability to solve problems during instruction. It does not limit on reading activity in the class but it can happen in some places like in the house, pin the car, the 
night before going to bed. In brief, it is used as subject and breaks the limit of a subject as general. Then, extensive reading has some benefits. It increases student ability in some linguistic aspect such as vocabulary, reading, and writing. It increases student's vocabulary because student finds and learns unknown vocabulary or strengthening the vocabulary that meet before. It effects on student reading ability because of student is able to make sense the text consequently on student ability in writing. Steiner (Mikeladzo, 2015:31)list some benefit of extensive reading "a) enhances world knowledge b)account for one-third of vocabulary growth c) promote reading as lifelong activity d) build vocabulary e)build structural awareness f)improves comprehension skills g) promote motivation $h$ ) encourages pupils to progress through different levels of the text and monitor their own progress $\mathrm{j}$ ) provides with enjoyable reading experiences"

In order to get the purpose of extensive reading, students should have attitude as impetus to follow extensive reading. Attitude is a set of belief around an object or situation. It could learn through teaching process because someone who neutral even someone who has positive belief would influences them. It could be generalized such as students who do not like learning and school, could generalize that the students is dislike. In addition, there are 3 components of attitude; affective, cognitive and behavior. The first component is affective. It is feeling related to an object or phenomena. Vishal Jain (Jain, 2014:6) said affective component is the emotional response (liking/disliking) toward an attitude component.It influences the students' further action toward an object or event. It is important component because the identifying of attitude cannot view only on students' self evaluation. The second component is cognitive. It is related to argument related to an object or phenomena. It is related to understanding about an object or phenomena. In this case, the cognitive is related to students' opinion related to extensive reading. It can be self- evaluation for students' who learns extensive reading in order to achieve the aims of reading extensively.The last component is behavior. It is related to response toward phenomena and object and it can be positive or negative. It is tendencies toward an object or phenomena and it is reflection of affective and cognitive. It means if the students have positive affective and cognitive, they will have positive tendencies toward an object or phenomena.

In general, there are some issues about attitude in extensive reading class found. Firstly, the students are reluctant to read (He and Green, 2012:34). It means the students do not have interest to reading. Takase in(He and Green, 2012:34)states readers who are not interest in reading are the third biggest concern shared by extensive reading practitirelate. It is caused students have lack confidence in term of read in English as a result the students are reluctant to read. Then, students think that reading in English is frightening activity which relates to difficult vocabulary and complex sentences structure. Secondly, the students have low reading habit (Meinawati, 2018:847) Students have to deal with print the reading material and students feel drowsy when they have to read some reading material especially when they have to read wide range text. It leads to low reading habit because the students tend to stop reading and do the other activity in order to keep awake like playing game etc.

In addition, there are two problem was found in the field. The first problem was the students were reluctant to read and they bored to read English reading text because the students found more than five difficult vocabularies. It did not fulfill the requirement to read the text extensively that the students should fun with the reading text. In addition, they were enthusiastic to read in the first and second meeting of extensive reading class but they bored to read in the third meeting. In addition,The second problem was the students have low reading habit. The students did not have reading material such as book and article, so they should find the text in internet then print the text. They did many task and they prioritize it meanwhile 
they forgot reading. Then, some of them told that sometime reading was bored and It led to low reading habit because students interest to follow extensive reading was low. Based on the problems above, it was important to do this research because the students' attitude was crucial to know as evaluation in order to get all of extensive reading objectives. Then, research under the title "Students' Attitude Toward Extensive Reading at The English Education Study Program in IAIN Bukittinggi"conducted

\section{Method}

This study was categorized into survey research. It was the one of procedures in quantitative research in which investigator administer a survey to a sample or to entire population of people to describe the attitudes, opinion, behaviors or characteristics of the population (Croswell, 2012:3) The population of this research was all of the second-semester students' academic year 2018/2019 and total sampling is used as sampling technique. Questionnaire is used as reserch instrument and it was adapted from Davis (Kalengkongan, 2015:2)which stated about 10 attitude related to extensive reading then, the data would interpret by using the following table

\begin{tabular}{cl}
\hline Score & Description \\
\hline $1,00-1,80$ & Not good \\
$1,81-2,61$ & Less good \\
$2,61-3,41$ & Good enough \\
$2,41-4,21$ & Good \\
$4,20-5,00$ & Very good \\
\hline Source : Sugiyono (2013:93)
\end{tabular}

\section{Finding and Discussion}

There were 3 statements about students affective attitude toward extensive reading. Then, the representation of students' attitude toward extensive reading in the aspect of affective and it is displayed with using the following table.

Table 1. Students' attitude tow ard extensive reading in aspect of affective

\begin{tabular}{llllll}
\hline Statements & Options & F & X & f.x & $\mathbf{M}=\mathbf{\Sigma}(\mathbf{f . x}) / \mathbf{n}$ \\
\hline \multirow{5}{*}{1} & Strongly Agree & 55 & 5 & 275 & $414 / 93$ \\
& Agree & 29 & 4 & 116 & \\
& Neutral & 6 & 3 & 18 & \\
& Disagree & 2 & 2 & 4 & \\
& Strongly & 1 & 1 & 1 & \\
Total & disagree & & & & \\
2 & & 93 & & 414 & 4,45 \\
& Strongly Agree & 30 & & $: 150$ & $378 / 93$ \\
& Agree & 41 & 4 & 164 & \\
& Neutral & 20 & 3 & 60 & \\
& Disagree & 2 & 2 & 4 & \\
Total & Strongly & 0 & 1 & 0 & \\
& disagree & & & & \\
& & 93 & & 378 & 4,06 \\
\hline
\end{tabular}




\begin{tabular}{llllll}
\hline Statements & Options & F & X & f.x & $\mathbf{M = \Sigma ( f . x ) / n}$ \\
\hline 3 & Strongly Agree & 7 & 5 & 35 & $332 / 93$ \\
& Agree & 44 & 4 & 176 & \\
& Neutral & 38 & 3 & 114 & \\
& $\begin{array}{l}\text { Disagree } \\
\text { Strongly } \\
\text { disagree }\end{array}$ & 3 & 2 & 6 & \\
Total & 1 & 1 & 1 & \\
\hline \multicolumn{5}{c}{ Source: reasearch data } \\
\end{tabular}

Source: reasearch data

Based on the above table there are 93 respondent. The data showed that there were 55 respondents who strongly agree toward the statement. Then, there were 29 respondent who agree with the statement, 6 respondent choose neutral, 2 person answer disagree and one respondent chose strongly disagree. In addition, the mean of the first statement is 4,45 and it means the students had very good attiude toward the first statement. The second point illustrated that the majority of the students chose agree, 41 respondents. Then, there were 30 respondent who strongly agree toward the statement. The table also showed 20 respondent who neutral, 2 person who chose disagree, and none of them who chose strongly disagree. Then, the average of the second statement was 4,06 which means the students had good attitude toward the second statement. The third point explained that popular answer was agree with 44 respondents chose it . Then, 38 respondents who undiced whether agree or disagree. 7 respondents chose strongly agree with statement, 3 respondents chose disagree with the statement and one respondent chose strongly disagree with the statement. In brief, the average of the data is 3,56 and it illustrated that the students the students had good attitude toward the third statement. In addition, there are five cognitive statement as follow:

Table 2. Students' attitude tow ard extensive reading in aspect of cognitive

\begin{tabular}{|c|c|c|c|c|c|}
\hline Statements & Options & $\mathbf{F}$ & $\mathbf{X}$ & f.x & $M=\Sigma(f . x) / n$ \\
\hline English education section & Strongly Agree & 51 & 5 & 255 & $407 / 93$ \\
\hline students should follow & Agree & 29 & 4 & 116 & \\
\hline extensive reading class & Neutral & 10 & 3 & 30 & \\
\hline with maximal in order to & Disagree & 3 & 2 & 6 & \\
\hline get many benefit & Strongly disagree & 0 & 1 & 0 & \\
\hline Total & & 93 & & 407 & 4,37 \\
\hline My reading skill was & Strongly Agree & 24 & 5 & 120 & $365 / 93$ \\
\hline developed cause of & Agree & 41 & 4 & 164 & \\
\hline \multirow[t]{3}{*}{ extensive reading class } & Neutral & 25 & 3 & 75 & \\
\hline & Disagree & 3 & 2 & 6 & \\
\hline & Strongly disagree & 0 & 1 & 0 & \\
\hline Total & & 93 & & 365 & 3,92 \\
\hline My vocabulary was & Strongly Agree & 21 & 5 & 105 & $360 / 93$ \\
\hline developed cause of & Agree & 44 & 4 & 176 & \\
\hline \multirow[t]{3}{*}{ extensive reading class } & Neutral & 23 & 3 & 69 & \\
\hline & Disagree & 5 & 2 & 10 & \\
\hline & Strongly disagree & 0 & 1 & 0 & \\
\hline Total & & 93 & & 360 & 3,87 \\
\hline My writing skill was & Strongly Agree & 13 & 5 & 65 & $332 / 93$ \\
\hline developed cause of & Agree & 37 & 4 & 148 & \\
\hline \multirow[t]{3}{*}{ extensive reading class } & Neutral & 33 & 3 & 99 & \\
\hline & Disagree & 9 & 2 & 18 & \\
\hline & Strongly disagree & 2 & 1 & 2 & \\
\hline
\end{tabular}




\begin{tabular}{|c|c|c|c|c|c|}
\hline Statements & Options & $\mathbf{F}$ & $\mathbf{X}$ & f.x & $M=\Sigma(f . x) / n$ \\
\hline Total & & 93 & & 332 & 3,56 \\
\hline My grammar skill was & Strongly Agree & 12 & 5 & 60 & $320 / 93$ \\
\hline developed cause of & Agree & 30 & 4 & 120 & \\
\hline extensive reading class & Neutral & 40 & 3 & 120 & \\
\hline & Disagree & 9 & 2 & 18 & \\
\hline & Strongly disagree & 2 & 1 & 2 & \\
\hline Total & & 93 & & 320 & 3,44 \\
\hline
\end{tabular}

Source: reasearch data

Based on above table, the first item explained the half of population or 51 respondents was strongly agree with the statement. Then, there are 29 respondents chose agree statement. There were 10 respondent chose neutral. There were 3 respondent chose disagree with the statement and none of them who strongly disagree with the statement. Then, the average of the item is 4,37 and it means the students had very good attitude toward this statement. The second item explained that the popular answer was agree with 41 respondents from total population. 25 respondents chose neutral and 24 respondent was strongly agree. Then, 3 respondent was disagree with the statament and none of them who chose stronly disagree. In conclusion, the mean of the data is 3,92 and it means the students had good attitude toward this statement. The third item showed that there were 21 respondent who strongly agree toward the statement, there were 44 respondents who agree, there were 23 respondents who chose neutral, 5 respondents who chose disagree, and one of respondent who chose strongly disagree. In brief, the mean of this item is 3,87 and it means the students had good attitude toward this items. The fourth statement showed that the majority of the respondent answered agree, 37 respondents, and the minority students answered strongly disagree, 1 respondents. Then, there were 13 respondents who strongly agree toward the statement, there were 33 respondents who neutral, 9 respondent chose disagree, and one respondents chose strongly disagree. In brief, the mean of this item was 3,56 and it means the students had the good attitude toward this statements. The fifth statemet showed that the popular survey was neutral, 40 respondents. Then, 30 respondents answered agree, 12 respondents chose strongly agree, 9 respondents chose disagree and 2 respondents answered strongly disagree. In addition, the average of this statement is 3,44 and it means the students had good attitude toward this statements.

Table 1. Students' attitude toward extensive reading in aspect of behavior

\begin{tabular}{llllll}
\hline Statements & Options & $\mathbf{F}$ & $\mathbf{X}$ & $\mathbf{f . x}$ & $\mathbf{M = \Sigma ( f . x ) / n}$ \\
Extensive reading had & Strongly Agree & 17 & 5 & 85 & $332 / 93$ \\
interesting lesson and & Agree & 36 & 4 & 144 & \\
activities so, I read & Neutral & 28 & 3 & 84 & \\
some text in a week & Disagree & 7 & 2 & 14 & \\
& Strongly & 5 & 1 & 5 & \\
\multicolumn{1}{c}{ Total } & disagree & & & & \\
There was a various & Strongly Agree & 93 & & 332 & $3, \mathrm{k} 1$ \\
text in extensive & Agree & 50 & 4 & 60 & $295 / 93$ \\
reading class so, I am & Neutral & 34 & 3 & 120 & \\
enthusiastic to write & Disagree & 6 & 2 & 12 & \\
weekly reading report & $\quad$ Strongly & 1 & 1 & 1 & \\
\multicolumn{1}{c}{ Total } & disagree & & & & \\
\hline
\end{tabular}


The first item illustrated that there were 17 respondent who strongly agree toward the statement, there were 36 respondent who agree, there were 28 respondent who neutral, 7 respondent who chose disagree, and 5 respondent who chose strongly disagree. In brief, the average of the first behavior item is 3,56 and it shows the students had good attitude toward this statement. The tenth item explained that the majority of respondent, 40 respondent agree with statement. Then, there were 12 respondent who strongly agree toward the statement, there were 34 respondent who neutral, 6 respondent who chose disagree, and one respondent chose strongly disagree. In conclusion, the average of the last behavior item is 3,17 and it explained that the students had good attitude toward the last statement.

\section{Conclusion}

Based on the finding and discussion above, it can conclude that:

1. The students attitude toward extensive reading in the aspect of affective is 3,56 and it shows the students have good attitude toward reading in the aspect of affective

2. The students attitude toward extensive reading in the aspect of cognitive e is 3,82 and it shows the students have good attitude toward reading in the aspect of cognitive

3. The students attitude toward extensive reading in the aspect of behavior is 3,36 and it shows the students have good attitude toward reading in the aspect of behavior

\section{References}

[1] Kathy G. Short and Jerome Harste. 1996. Creating Classrooms for Authors and Inquires. Portsmouth, NH: Heinemann.

[2] Mohammad Ali Erfanpour. 2014. The Effect of Intensive and Extensive Reading Strategies on Reading Comprehension: A Case of Iranian High School Students.English for Specific World ISSN 1682-3257 Issue 41, volume 14, 2013 page 1

[3] Tamar Mikeladzo. 2015. Extensive Reading. Research Gate. Download on October 11st 2018 at 10.39https://www.researchgate.net/publication/280878633p. 31

[4] Vishal Jain. 2014. 3D Model of Attitude. Vol 3 No 3. International Journal of Advanced Research in Management and Social Science. ISSN : 2278-6236 p. 6

[5] He., M., \& Green, CF. (2012). Challenges in Implementing Extensive Reading in Shanghai Senior High School Extensive Reading World Congress Proceedings, 1, 34-36 p.34

[6] SittaMeinawati. 2018. Extensive Reading in Indonesia and Its Challenge of Implementing It. Proceeding/International Seminar on English LanguageTeaching and Research (ELTAR) p. 847 